\title{
Optimization of Zakat for Sustainable Development Goals: \\ Evidence from Baitul Mal Aceh
}

\author{
Suriani, Ridwan Nurdin \& Muhammad Haris Riyaldi \\ Universitas Syiah Kuala
}

Paper to be presented at the $4^{\text {th }}$ International Conference of Zakat (ICONZ)

7-8 October 2020, Surabaya, Indonesia

\begin{abstract}
Zakat is a wealth distribution mechanism that has an impact on reducing poverty as the most important point in achieving the sustainable development goals (SDGs). An important role can be played by zakat institutions, especially in regions in Indonesia. This study aims to explain the mechanism of zakat as an instrument of the Islamic economy to contribute to the achievement of SDGs in Aceh Province by optimizing the role of the Baitul Mal Aceh. Using the grounded research method, this research is carried out by collecting data through interviews with academics of Islamic studies, Islamic boarding school scholars, and zakat practitioners who are competent to assess the role of zakat in poverty alleviation in Aceh. The results showed that to achieve the sustainable development goals (SDGs) Baitul Mal Aceh must optimize zakat as a transfer of wealth from muzakki to mustahik, both optimizing the collection and optimizing the distribution of zakat. Optimization of zakat collection is carried out by zakat education, socialization, and good zakat services, while optimization of distribution is carried out by prioritizing zakat for poverty alleviation programs, ensuring the accuracy of zakat recipients, and distribution using consumptive and productive methods.
\end{abstract}

Keywords: zakat collecting, zakat distribution, SDGs

\section{INTRODUCTION}

One of the obligations of Muslims is to pay zakat. In the text of the Qur'an, it is explained about zakat in 82 verses, even 28 verses of which are related to the obligation to perform prayers (Ash-Shiddieqy, 2009). This confirms the high position of zakat and the importance of zakat worship so that it is carried out by Muslims.

Zakat has an important role in welfare development. The impact of zakat can be felt not only by someone paying zakat (muzakki), but also by having a positive impact on the recipients of zakat (mustahik). Zakat for muzakki is a form of servitude (ta'abbudi) to Allah SWT by setting aside one's assets to help others, so that the purity of the soul is manifested from being stingy and the sanctity of the treasure is guaranteed. Whereas for the mustahik, zakat is helping to poverty problems. In other words, zakat is a form of worship that has the dimensions of a servant's relationship to Allah SWT (hablumminallah), as well as a relationship between humans (hablumminannas).

Zakat is a mechanism for the transfer of wealth from the rich to the poor. Therefore, zakat must be managed properly to function as an economic mechanism which has implications for increasing the economic productivity of the lower classes, increasing aggregate consumption, increasing aggregate investment, and subsequently increasing employment (Furqan, Mulyany, Yunus, 2018). Thus the distribution of zakat can overcome the influence on economic growth and development in a country.

The distribution of zakat that is development-oriented can be an effort to overcome the problem of poverty. Because 
basically the needy and the poor are the main groups as the target recipients of zakat. The trend of poverty which continues to decline in Indonesia in line with the increase in the amount of zakat shows the negative effect of zakat on poverty.

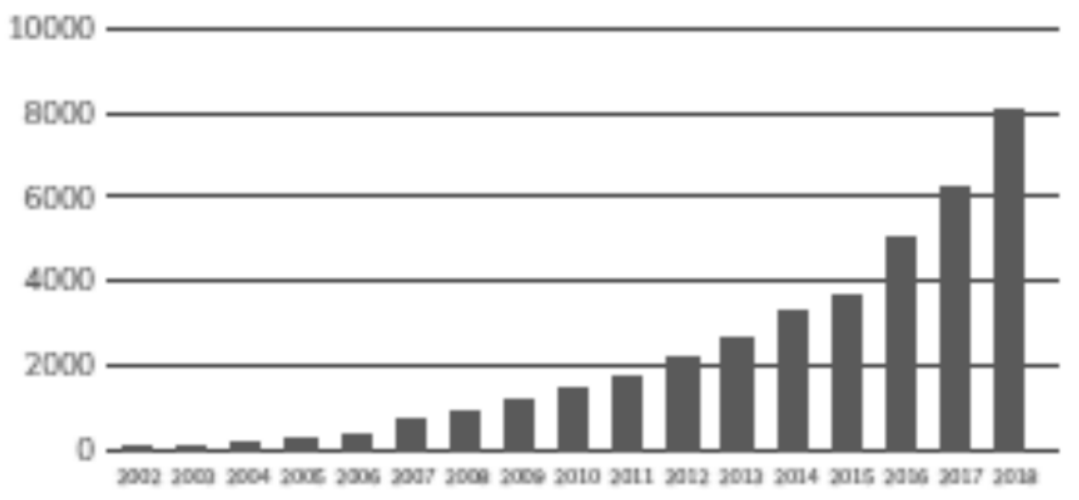

Figure 1. Development of Zakat Collection in Indonesia in 2012-2018

Figure 1 shows the trend of zakat collection which has continued to increase from 2002 to 2018. A significant increase occurred from 2016 to 2018. Overall in the last 3 years, there has been an increase in zakat of 122 percent or IDR4.5 trillion.

When the zakat trend shows an increase, at almost the same time the poverty rate in Indonesia shows a downward trend. Figure 2 shows the poverty rate in Indonesia from 2012 to 2019.

In Figure 2 it can be seen that the poverty rate in Indonesia is decreasing every year. This shows that national development has succeeded in increasing the welfare of its population. And if it is related to zakat funds that are distributed annually to the poor in Indonesia, it can be said that zakat has contributed to reducing poverty.

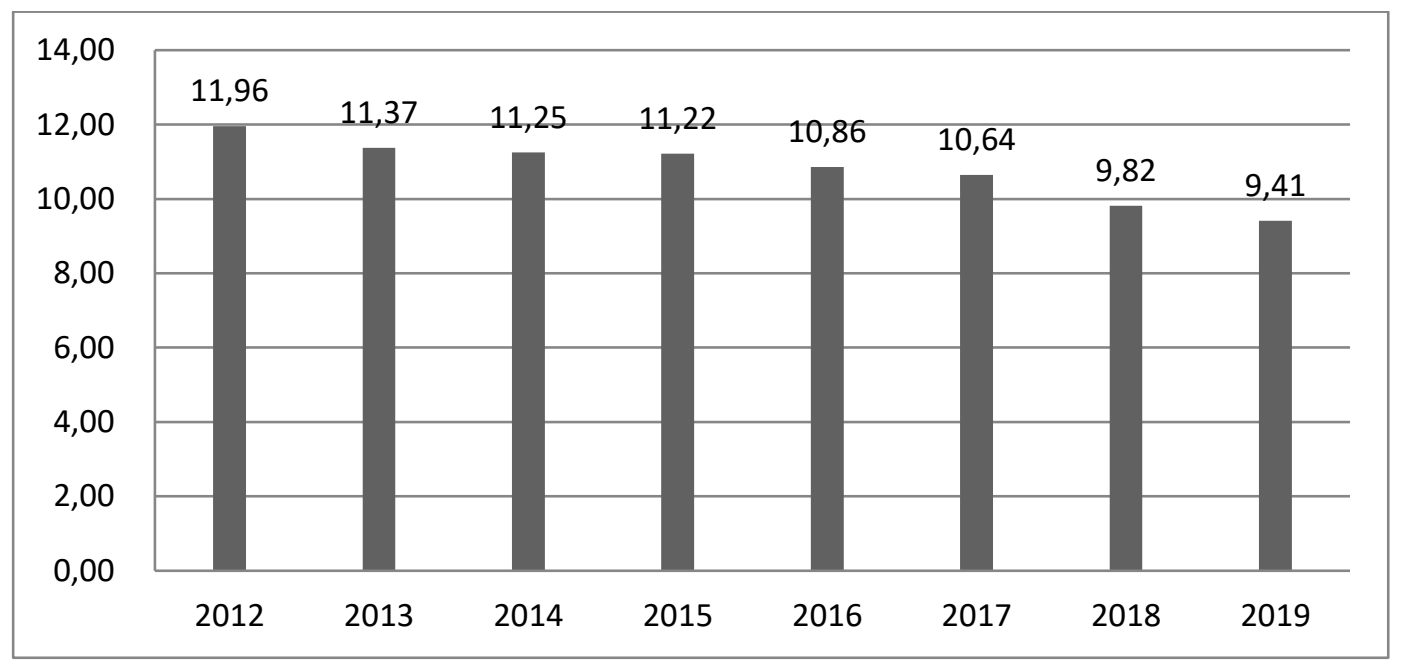

Figure 2. Poverty Level in Indonesia 2012-2019

The various activities of zakat distribution by managing organizations can be said to be trying to achieve development goals, namely to prosper and provide justice for the community, especially mustahik / people who have the right to receive zakat. 
The management of zakat, in general, is carried out through programs and activities, which, if grouped into fields, in the form of consumptive direct assistance/assistance programs, education programs, health programs, community economic empowerment programs, and emergency programs, indicates that alignment with the Sustainable Development Goals (Puskas BAZNAS, 2017).

The SDGs which were initiated by the United Nations (UN) are a global development agenda that have become a consensus involving 193 countries in the world, including Indonesia. The SDGs contain a set of transformative goals that were agreed upon and applied since 2016 for all (universal) UN member countries, both developed, poor, and developing countries. The SDGs contain 17 development goals, including eradicating poverty (SDGs 1), ending hunger (SDGs 2), and achieving good health (SDGs 3). At first glance, this goal is closely related to the purpose of distributing zakat. The study of Puskas BAZNAS (2017) shows that SDGs points 1,3 , and 2 are priority groups of zakat towards SDGs.

The Indonesian government is committed to being a pioneer and pilot model in achieving the SDGs. Governments at the provincial and district levels are also working with partners to plan and prioritize how the SDGs will be achieved. Local government work is very important because of the decentralized system of governance in Indonesia. This means that decisions about how public funds, including zakat, are used for public services, such as health, education, infrastructure development, and poverty alleviation have been made at the local government level (Noor, 2017).

Studies that raise the topic of zakat concerning the achievement of the SDGs are found to be still limited. Apart from the BAZNAS Puskas (2017), Khalifah, Nurzaman, Nafis (2017) and Amymie (2017) also raised a slice of zakat distribution. However, Amymie (2017) raises a study of zakat distribution in BAZNAS West Java with the implementation of SDGs in the aim of reducing poverty and hunger. The two Puskas BAZNAS studies (2017) and Khalifah, Nurzaman, Nafis (2017) used the Analytical Network Process (ANP) results from the data from Focus Group discussions (FGD) with zakat experts and practitioners, while Amymie used qualitative data analysis from the results of field research. Meanwhile, Shaikh and Ismail (2017) and Rohim (2019) conducted a study through a literature review regarding the role of zakat as a fund to improve social welfare in achieving the SDGs. In more detail, Harahap (2018) examines the concept that links zakat funds as a starting point for overcoming poverty through funding for small businesses of mustahik entrepreneurs. This study is in line with Rassanjani, S (2018) which states that zakat is alternative funding for achieving SDGs 1 (without poverty).

The results of the existing studies have raised a tight slice of the role and potential of zakat funds and the achievement of the SDGs. However, no study has been found regarding the zakat mechanism to optimally realize this mechanism through zakat management institutions in the provinces, let alone the study at Baitul Mal Aceh Province. The phenomenon of Aceh province as a region that has strong regulations regarding zakat management, namely Aceh Qanun No. 10 of 2018, but still experiencing high poverty rates. Therefore, this study describes the zakat mechanism as an Islamic economic instrument with the dimensions of fardhiyyah and muamalah (economic and social) worship that can contribute to the achievement of SDGs in Aceh Province and how this role can be achieved effectively through the Aceh Baitul Mal. These are the issues discussed in this scientific article with a detailed discussion in the research results section. 


\section{LITERATURE REVIEW}

\section{Optimization of the Role of Zakat for Development}

Poverty and income inequality are problems faced by governments of developing countries. One of the important sectors in the Islamic economy to overcome this problem is the distribution of assets through zakat. Zakat is a pillar in Islam which is related to its role in the distribution of wealth (income) from groups that have excess assets (aghniya) to groups who experience a lack of assets (Huda et al., 2015).

In optimizing the role of zakat, Islam teaches aghniya to realize that the obligation of zakat is very important for themselves and their assets. In Islam it is taught that there is a share of the poor in the wealth of every rich person. As Allah SWT says: "And on their property, there is a right for poor people who ask, and poor people who don't ask" (Surah Adz-Dzariyat [51]: 19). Therefore, part of the wealth of the aghniya must be given to the needy and poor. By giving zakat, then elevating human dignity can avoid the love of wealth and farthest from the attitude of like to accumulate wealth. In the al-Qur'an, it is stated that: "take sadaqah from their wealth by which you might purify and cleanse them" (Surah At-Tawbah [9]: 103). The Qur'an also reports the threat of grievous punishment for those who do not pay zakat. In Surah at-Taubah [9] verses 34 and 35 it states a form of torment for those aghniya who do not pay zakat that their property will be heated in the hellfire of hell and then their foreheads, stomachs, and their backs will be burned.

Zakat becomes a guarantee for the flow of wealth distribution in the middle of people's lives. If this distribution of assets does not go well, then the poor will not be able to fulfill the most basic needs of their lives (Fauzia and Riyadi, 2015). Therefore, from the beginning it was ordered to worship zakat, then the Prophet Muhammad SAW formed amil zakat.

The existence of amil zakat is a step to optimize the function of zakat to run well. Amil zakat plays a role in collecting zakat from muzakki and then distributing it to groups of people who are entitled to receive it. This role must be performed skillfully and professionally to achieve a strategic zakat function (Riyaldi, 2020). In order to ensure professionalism, amil is ideally a formal institution under the government capable of optimizing the collection and allocation of zakat funds efficiently and effectively (Hafidhuddin, 2011).

Zakat managed by amil professionals ensures that zakat distribution runs effectively. Economic, social, and spiritual goals can be achieved if zakat is allocated to 8 groups as stated in the alQur'an (Marthon, 2004). Allah SWT said:

"Zakat is only for the needy, the poor, amil zakat, who has softened his heart (converts), for (frees) my slave, for (frees) those who are in debt, for the way of Allah and for those who are on their way. as an obligation from Allah. Allah is AllKnowing, All-wise. " (Surah At-Tawbah [9]: 60)

The effects of zakat on recipients include zakat liberates its recipients from material needs, and zakat cleanses jealousy and hatred (Yusoff, 2008). Meanwhile, Marthon (2004) explains the impact of zakat on development, namely: increasing production, encouraging investment, creating jobs, reducing social disparities, and increasing economic growth. This indicates that the zakat mechanism can realize efforts to reduce poverty sustainably. The considerations include: first, zakat is some certain rights of the poor that are attached to the wealth of the rich (Armiadi, 2008). Second, the potential source of zakat is enormous. Even zakat is taken from all income generated from physical and financial assets and work 
skills (profession). This is an important capital to finance poverty alleviation programs. Third, zakat is a spiritual obligation of a Muslim that must be fulfilled as demand for faith in any economic-political condition. Therefore, the receipt of zakat tends to be stable and this ensures the sustainability of poverty alleviation (Huda et al, 2015).

\section{The Relevance of Zakat and SDGs}

Poverty is a problem that needs to be addressed in the right way. Islam views poverty as a problem that needs to be resolved using scientific and realistic means of solving poverty. Islam is present to provide a means of settlement that is excavated based on divine sources that are suitable for every individual or group of society. The means in question are work and zakat. Work is a conscious human effort to create goods or services. A person who works will have an income that can be used to meet the needs of himself and his family. By working, a person avoids hoping and begging others (Qardhawi, 2009). However, the reality in life shows that there are people who are unable to work and are already working but do not get sufficient results for themselves and their families. In Islam, people with this condition should be helped by zakat.

Zakat is a basic obligation for Muslims as fardhiyah (individual) worship in Islam. However, the function of zakat is other than a realization of a Muslim's sense of faith, the implementation of the zakat obligation has a social character. This means that zakat is a form of worship that fulfills a servant's relationship with Allah SWT, as well as strengthens human relationships. Zakat is a help for the poor and people who need financial assistance. Zakat given to the needy and poor can help ease the economic burden they face. Zakat funds can be used to fulfill their daily needs, both material needs, and spiritual needs. Thus, needy and poor people become capable in their lives to obey Allah SWT (Armiadi, 2008).

Ruziah Ghazali (2011) states that the distribution of zakat in addition to improving the economy should also be able to improve the quality of life of mustahik. Zakat can be a source of support for funds because zakat is aimed at reducing poverty and ensuring social justice. In Islam, the vision of human well-being does not only revolve around the realization of equal distribution of income and wealth but also to fulfill spiritual and non-material needs (Asmalia, 2018). Therefore, zakat can be one of the strategic instruments in realizing the economic development of the ummah that meets the elements of maqashid sharia.

Zakat as an instrument of Islamic economic development places the maqashid of sharia as the objective of its implementation, as is the concept offered by Al-Ghazali. Al-Ghazali formulated maqashid sharia into 5 (five) aspects and focused on fulfilling it. These aspects are rreligion, soul, intellectuals, heredity and assets. If Maqashid sharia is associated with the achievement of the SDGs, then almost all points on the SDGs are on the same path as maqashid sharia. However, the SDGs coverage is narrower than the sharia maqashid because the SDGs only cover part of the substance of the 4 (four) components of the maqashid sharia apart from religion. Even so, the SDGs can be used as a reference for intermediate goals for zakat to fulfill the major development goals reflected in the maqashid sharia (Puskas BAZNAS, 2017).

\section{RESEARCH METHOD}

This study uses a qualitative approach with Grounded Research (GR). The grounded research (GR) method is a research method that is based on facts and uses comparative analysis aimed at making empirical generalizations, establishing concepts, proving theories and developing theories in 
which data collection and data analysis are carried out at the same time. This method emphasizes theoretical discovery from empirical observation data in the field with the inductive method or finding a theory from several data (Sudira, 2009).

In finding relevant data to answer research problems, in-depth interviews with informants were used. Interviews were conducted with experts consisting of academics (informant 1) and pesantren scholars (informant 2) who have experience researching zakat and are actively involved in the formulation of zakat policies in Aceh Province. Furthermore, data deepening was also carried out by interviewing zakat practitioners (informant 3) who are involved as policy makers in zakat management in Aceh Baitul Mal.

Table 1. Research Informants

\begin{tabular}{clll}
\hline Informan & Name & Position & Institution \\
\hline $\mathbf{1}$ & Nazaruddin A.Wahid & Academics (professors) & $\begin{array}{l}\text { Universitas Islam Negeri } \\
\text { (UIN) Ar-Raniry, Banda } \\
\text { Aceh }\end{array}$ \\
\hline $\mathbf{2}$ & Masrul Aidi & Islamic scholars (ulama) & $\begin{array}{l}\text { Pesantren Babul Maghfirah, } \\
\text { Aceh Besar }\end{array}$ \\
\hline $\mathbf{3}$ & Armiadi & $\begin{array}{l}\text { Zakat practitioner } \\
\text { (chairman) }\end{array}$ & Baitul Mal Aceh \\
\hline
\end{tabular}

The data of this study are qualitative in the form of informants' opinions regarding efforts to optimize zakat in achieving SDGs in Aceh Province. The collected data is then analyzed with steps consisting of data reduction, data display and verification, and triangulation of data for concluding.

\section{RESULT AND DISCUSSION}

Zakat Management Mechanism in Achieving SDGs in Aceh

The management of zakat in Aceh is different compared to other provinces in Indonesia. The main difference is the existence of the Baitul Mal as the official institution responsible for managing zakat in Aceh. The existence of the Baitul Mal is actually a continuation of the Amil Zakat, Infaq and Alms Agency (BAZIS) which was formed in 1995. The change of BAZIS to the Baitul Mal Body began with the issuance of Governor Decree No. 18/2003 concerning the Establishment of the Organization and Work Procedure of the Baitul Mal Agency for the Province of
Nanggroe Aceh Darussalam (NAD), which began operating in January 2004 (BMA, 2020).

Baitul Mal is a partner for regional heads, both Governors and Regents/Mayors, in the context of managing zakat assets and other religious assets. As a zakat management institution, the vision of Baitul Mal Aceh is to become a trustworthy, transparent, and accountable institution. Baitul Mal Aceh sets the mission to achieve this vision, namely:

1) Optimizing the socialization and education of ZISWAF and the role of baitul mal

2) Developing a certified amil competence

3) Implementing Total Quality Management in ZISWAF Management

4) Realizing Technology-Based Data and Information Management

5) Optimizing the collection of zakat and infaq

6) Realizing the distribution and utilization of zakat and infaq that contribute to increasing productivity and independence in society 
7) Improve the management of waqf and guardianship of orphans

Highlighting the mission of BMA in operating the zakat mechanism to build community welfare, the 5th and 6th missions become important points. BMA is an institution that plays an important role in ensuring the transfer of muzakki assets to mustahik (asnaf zakat). The mechanism can be illustrated in Figure 3.

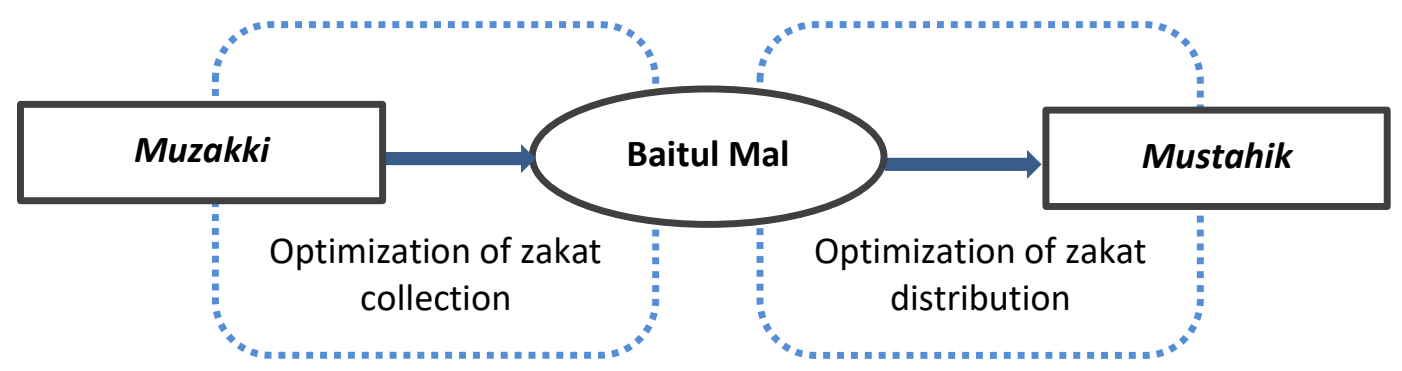

Figure 3. Optimization of Zakat Mechanism to achieve SDGs

In achieving the SDGs goals through the zakat mechanism, the function of Baitul Mal in Aceh is to optimize the collection of zakat from muzakki, so that zakat can be distributed and utilized effectively to mustahik. If the collection optimization goes well, then the funds used to optimize the distribution of zakat in poverty alleviation programs can be effectively implemented. Thus, zakat can play a role in the distribution mechanism of assets which in a sustainable manner affects on improving the welfare of mustahik, especially those from the needy and poor.

Optimizing zakat in sustainable development in Aceh Province at least has contributed to economic growth and poverty reduction.

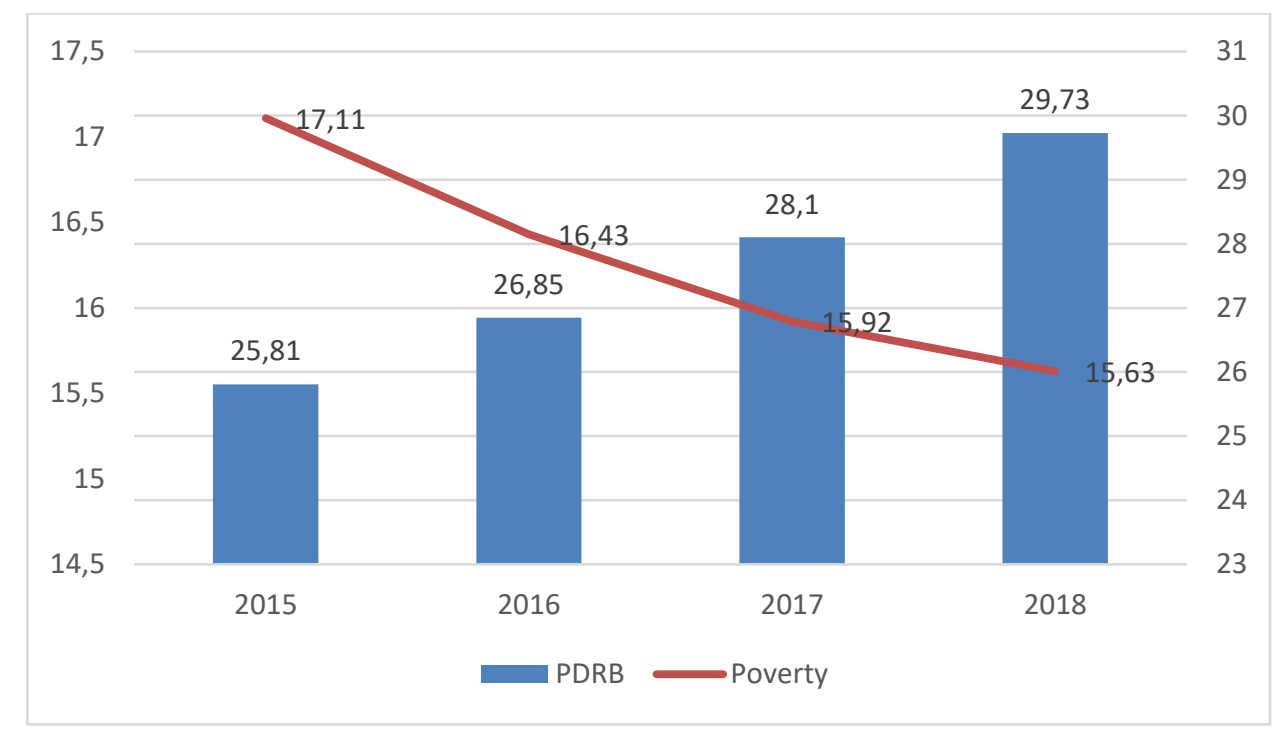

Figure 4. GRDP and Poverty Level in Aceh Province

In Figure 4, it can be seen that there is an increase in GRDP every year in Aceh Province by an average of 1.3 percent. Inversely proportional to poverty, the poverty rate has decreased by an average of 0.49 percent. Although economic growth and poverty reduction are not fully influenced by zakat, it can be said that zakat 
is part of poverty reduction policies. Poverty alleviation is the responsibility of the government, while the role of zakat is in this responsibility even though the portion is not large. Yusoff (2008) states that the responsibilities of each government in the country are broader in scope than the zakat institution.

Optimizing Zakat to Achieve SDGs

Aceh Province is known as a special autonomous region in Indonesia which officially implements Islamic law. Besides, the majority of the population residing in Aceh is predominantly Muslim. In optimizing zakat as a driver of social welfare, regulations related to zakat management are issued in the form of Qanuns (regional regulations). Besides regulations, efforts to optimize zakat have been carried out by Baitul Mal, both in optimizing the collection and distribution of zakat.

1. Optimizing Zakat Collection

Since the establishment of Baitul Mal in Aceh Province, the amount of zakat that can be collected has increased every year. This is an indicator that the awareness of the Acehnese people to fulfill zakat is good. Informant 3 explained:

"The awareness of the Acehnese paying zakat is categorized as high. For example, even though farmers are poor, at harvest time, before the harvest is brought home, they have already completed 10 percent of their zakat."
Although public awareness is good, there is still a gap between the potential for zakat and the realization of zakat collection in Baitul Mal. Informant 1 Statement:

"In reality, the gap between the potential for zakat and its revenue is still far away. Among the reasons, namely: 1) zakat is recorded only in Baitul Mal, even though people pay a lot of zakat outside the Baitul Mal. 2) the understanding of zakat in society is friction/difference. Some think that paying zakat directly to mustahik is better than official institutions. Because they think there is a social cost or direct effect on zakat recipients. So if they pay directly there are two things that are obtained, namely the function of zakat and the benefits of zakat. Our society still lacks trust in official institutions under the government. It can be concluded that the trust factor in Baitul Mal is still weak."

The trust factor is a factor that causes the community not to submit their zakat to Baitul Mal, so it is not recorded in the zakat collection data. Therefore, Baitul Mal made efforts so that the community who became Baitul Mal muzakki could increase. Data on the increase in muzakki experienced by Baitul Mal Aceh from year to year are as presented in Table 2.

Table 2. Amount of Muzakki and Zakat Collected in Baitul Mal Aceh 2016-2018

\begin{tabular}{cccc}
\hline Year & The Number of Muzakki & Zakat Collection (Rp) & Growth (\%) \\
\hline 2015 & 6.161 & 27.312 .498 .281 & - \\
2016 & 9.528 & 27.970 .836 .358 & 2,35 \\
2017 & 23.584 & 53.427 .890 .289 & 47,65 \\
2018 & 22.342 & 54.014 .187 .358 & 1,09 \\
2019 & & 89.058 .367 .527 & 39,35 \\
\hline
\end{tabular}

Source: Directory of Baitul Mal Aceh Tahun 2015-2019 
Baitul Mal has optimized the collection of zakat in Aceh through socialization and education of zakat and good service in paying zakat. This is as conveyed by Informant 3 as follows:

"Baitul Mal conducted
socialization, especially
regarding the existing zakat
regulations. Planned outreach is
carried out annually to employees
in government agencies and
companies and other potential
sources of zakat. In addition,
Baitul Mal also optimizes services
in paying zakat, both directly and
through online (digital) media. "

Based on the statement of informant 3, it is known that there are 3 (three) methods of optimizing zakat collection, namely: zakat education, socialization and optimal services.

a) Zakat education

In optimizing the collection of zakat through education, it can be carried out through 2 (two) channels, namely: formal education (official) and informal education. Informant 1 explained:

"Formal education is carried out through teaching about the knowledge of zakat taught in schools. Second, informal education such as lectures, sermons, print media, and electronic media."

Baitul Mal also created an educational program by circulating reading material about zakat to the public. Informant 3 stated that:

"Education is carried out through the media of magazines and recitation which I do regularly in the mosques."

Formal zakat education should have been carried out from an early age and has been completed by every Muslim at the primary education level. As said by Informant 2 as follows:
"Zakat as a pillar of Islam must have been mastered at the basic education level. So at the age of adulthood, people already understand the basics of Islam, including the basics of zakat worship, such as: the law of zakat, and what assets are obligatory zakat. Because zakat worship is not related to age, but related to property (wealth). A child who is orphaned, but has assets that reach nishab, he must pay zakat on his assets."

The importance of education is closely related to efforts to make people aware of the obligation of zakat. As informan 1 states:

"There are 3 pillars of the importance of zakat education.

First, the Pillars of Rationalization of zakat, which is to make people aware that the risk of not paying zakat is large, for example, not paying zakat can be isolated by the community. Second, the Social Exchange Pillar (social exchange), meaning that if you pay zakat, the poor in front of my house will be helped in life. Third, the pillars of formal and informal leaders, namely role models / good examples from officials to pay zakat to Baitul Mal. These three pillars are necessary to build public awareness."

b) Socialization of zakat

Socialization is an effort to disseminate information related to zakat collection. Baitul Mal conducts zakat socialization intensively to disseminate zakat payment information to Baitul Mal. As informant 3 stated that:

"Baitul Mal has been
aggressively socializing,
especially regarding existing
regulations. Apart from that,


BMA mainly carries out planned socialization every year for other agencies and zakat potential."

Baitul Mal planned out a socialization agenda under the coordination of the Head of Socialization and Development (Sosbang) Baitul Mal. As it is said that in 2017, the Sosbang sector carried out several socialization programs, both through print and electronic media as well as other socialization media. In 2017, there were around 100 Aceh Baitul Mal banners circulating in corners of the city such as on the fences of mosques and other public places. In socializing zakat, Baitul Mal also implements advances in information technology. Website and social media are one of the supporters to promote Baitul Mal Aceh. The Baitul Mal Aceh website can be accessed at www.baitulmal.acehprov.go.id.

Meanwhile, the social media used are Twitter with the @baitulmalaceh account, and Facebook with the Baitul Mal Aceh account and Instagram @baitul_mal_aceh (Annual Report, 2017). c) Good services to muzakki

People who meet the criteria as muzakki can choose various ways to pay zakat at Baitul Mal Aceh. In addition to the direct payment method through the zakat collection unit (UPZ), muzakki can choose services to pay zakat through online digital media. As informant 3 stated:

"Baitul Mal optimizes services in paying zakat, both directly at the office, and through existing media so that people do not need to come to the BMA office to use online media, such as zakat payments using QRIS. So, the development of information technology media is optimized by Baitul Mal. "

With various zakat payment services, muzakki are interested in submitting their zakat to Baitul Mal. Therefore, optimal service is one of the causes of an increase in the amount of zakat received in Baitul Mal, both at the provincial and district/city levels in Aceh.

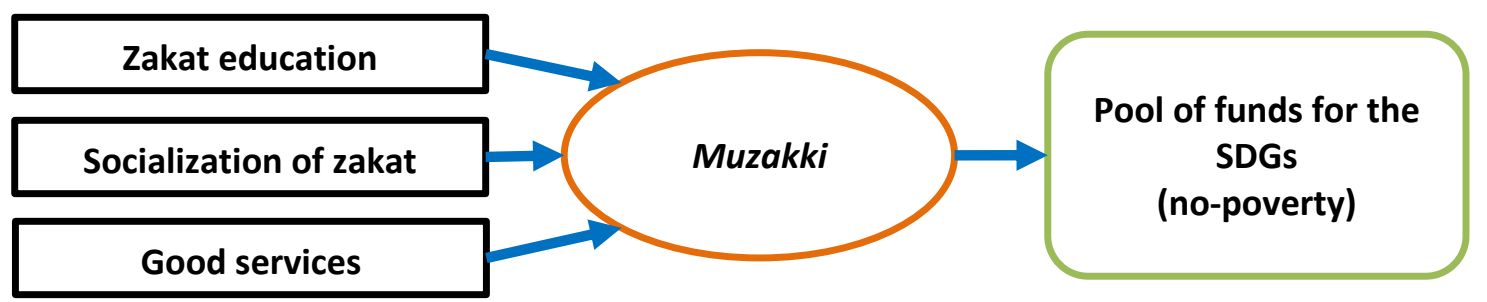

Figure 4. Optimization of zakat collection to achieve SDGs

2. Optimizing the distribution of Zakat

The distribution of zakat by Baitul Mal is carried out by running programs in the social, education, economic and da'wah sectors (syiar Islam) to all zakat asnaf, except riqab (freeing slaves).

a) The social sector, including activities: monthly elderly compensation, Ramadhan assistance, assistance for children and women victims of violence, incentive assistance, assistance for new converts, assistance for displaced people/run out of supplies, assistance for cancer and thalassemia sufferers, renovation of aged homes and renovations mosques/meunasah in areas prone to aqidah/Aceh border. 
b) The education sector, which includes activities: full scholarships for converts to sharia converts, assistance for converting children to new converts in areas prone to aqidah, full scholarships for the al-Quran for junior and senior high school levels, full scholarships for entrepreneurship Islamic boarding schools, full scholarships for Diploma and Undergraduate students, assistance Continuing education for outstanding students at the elementary, junior high and high school levels, sustainable tahfidz scholarships for student levels, education assistance for D3 and undergraduate students who are completing their final assignments, assistance for poor orphans at the elementary and junior high school levels, ongoing assistance for students with tahfidz Al-Quran, and life training skill.

c) The economic sector, including activities: work equipment assistance, business capital assistance through Baitul Mal Gampong, and business capital assistance for converts.

d) Da'wah/ syiar Islam sector includes activities: assistance for Islamic organizations and symbols, and assistance for zakat seminars/discussions.

In achieving the goal of sustainable development in Aceh Province, the zakat program is prioritized for the needy and the poor. As informant 3 stated that:

"Helping the poor is a priority program of BMA. Because zakat distribution to the poor in fiqh uses the principle of priority. Based on Q.S. At-Taubah: 60, the poor asnaf first declared as the main asnaf. Thus the zakat distribution program is designed to solve a large portion of the problems of the poor. "

Based on this statement, it can be said that the main target of zakat distribution is asnaf the needy and the poor. This is because the purpose of zakat is to overcome the problem of poverty. Informant 2 explained that the seven zakat was distributed to the poor and the poor, so that zakat would become a means of empowerment.

"The purpose of zakat is to empower the poor so that their degrees are lifted and they can get out of poverty."

The empowerment of the poor by distributing zakat was also stated by informant 1 as follows:

"The distribution of zakat aims to reduce the number of zakat recipients. For example, in our previous village the number of mustahik was 300 people, can this year's zakat decrease to 200? Don't increase to 350 people. So Amil zakat must think like that so that changes occur. Broadly speaking, there are two changes. First, there is a shortage of the poor in an area or a reduced number of poor people. Because every needy person has tried to improve his life. Second, it is not poverty that does not exist but feeling ashamed to receive zakat."

Based on the statement of informant 1 , the indicator of the success of the distribution of zakat is the changes that occur due to the distribution of zakat. These changes include declining poor zakat recipients and the paradigm of people who are ashamed to continue receiving zakat.

To achieve the goal of SDGs (no poverty), the optimization of zakat 
distribution is carried out by carrying out 3 (three) things, namely: priority zakat allocation for poverty alleviation programs, striving for targeting accuracy and using two methods, namely consumptive and productive zakat distribution. More clearly, it is detailed as follows:

a) Prioritizing zakat for poverty alleviation programs

Baitul Mal carries out zakat distribution by making asnaf the poor and poor as asnaf who receive the largest portion of zakat distribution. Apart from being a realization of the interpretation of sharia, this is done because there is still a very large number of poor people in Aceh. As explained by informant 3 that zakat is prioritized for asnaf needy and poor.

"Helping the poor is a priority program of BMA. This means that the portion allocated to asnaf for the poor is very large (dominant). Zakat allocation for the poor consumes more than 50 percent of the total zakat distributed."

The policy that zakat is given as dominantly and a large portion for asnaf for the needy and the poor can make a major contribution to poverty alleviation in Aceh. This policy was determined based on mustahik data held by Baitul Mal, while budget determination was determined by the government together with the Aceh legislative council in the form of budget allocations. This is as explained by informant 3 as follows:

"The determination of the portion of zakat distribution in the government budget allocation as a consequence of zakat becomes Aceh Regional Original Income (PAD) by Article 191 of Law no. 11 of 2006 concerning the Government of Aceh. This is what distinguishes the distribution of zakat in Aceh compared to other regions in Indonesia. "

This policy is expected to affect changes in the poverty rate. Informant 1 explained that:

"For the poor who receive zakat, zakat can change their fate. The fate that was previously destitute or poor can change to become richer."

Table 3. Zakat Distribution for Needy and Poor Asnaf 2015 s.d. 2019

\begin{tabular}{cccccc}
\hline \multirow{2}{*}{ No. } & Year & Needy (Rp) & Poor (Rp) & Amount (Rp) & $\begin{array}{c}\text { Allocation } \\
\text { percentage (\%) }\end{array}$ \\
\cline { 3 - 6 } & & & & & Zakat Allocation \\
\hline 1. & 2015 & 5.681 .865 .000 & 7.312 .381 .000 & 12.994 .246 .000 & 47,6 \\
\hline 2. & 2016 & 7.063 .800 .000 & 12.609 .600 .000 & 19.673 .400 .000 & 70,3 \\
\hline 3. & 2017 & 9.161 .800 .000 & 10.818 .090 .000 & 19.979 .890 .000 & 37,4 \\
\hline 4. & 2018 & 9.766 .000 .000 & 19.442 .889 .693 & 29.208 .889 .693 & 54,1 \\
\hline
\end{tabular}

b) Ensuring the accuracy of zakat recipients

Baitul Mal Aceh provides zakat allocation based on the data of its zakat recipients. Informant 3 said that:

"Something that is mandatory for BMA to have a mustahik database. So the distribution of zakat to the poor is based on data. Not only a database, BMA also has a Standard Operational Procedure (SOP) for zakat distribution. The mustahik database is also continuously updated. If it is considered that the mustahik of the poor asnaf is capable, then it is no longer 
included in the poverty-stricken database."

Informant 2 also conveyed the importance of collecting data to ensure the accuracy of zakat recipients. He stated that Baitul Mal must verify data on the poor in Aceh. As the opinion of informant 2 is as follows:

"Determining the poor in society requires good data collection. So this responsibility lies with the government. Because the government knows the best about the situation of its people. Poor not only see the appearance in his life. Therefore, Baitul Mal must verify the poor. "

The Baitul Mal Aceh continues to make efforts to realize zakat recipients' accuracy, including by involving Baitul Mal administrators at the village level to verify zakat recipients. In addition, but also has a zakat supervision division that is tasked with ensuring the validity of zakat recipient data. As informant 3 explains the following:

"BMA involves many parties, especially Baitul Mal Gampong. $B M G$ certainly involves village leaders (Keuchik) and community leaders. Likewise, the Baitul Mal in regent/city also coordinates with BMA. Apart from that, BMA has a supervisory area. This field performs a very strict mustahik verification task. And there is no discrimination against mustahik. BMA realizes that targeting accuracy and overlapping assistance is a sensitive issue. Routine assistance from other institutions is also a consideration for prospective BMA mustahics. This is so that help does not accumulate on some people. "

The accuracy of targeting ultimately makes the distribution of zakat can be done fairly to the poor. Zakat does not accumulate received by certain parties, thus creating a comfortable atmosphere in people's lives.

c) Consumptive and productive zakat distribution

The distribution of zakat to meet the consumption needs of the poor and the poor is the main thing done by zakat institutions. As stated by informant 1 in conveying the economic objectives of zakat, namely as follows:

"From an economic point of view, zakat can increase the consumption of mustahiks. With the transfer of zakat from the rich to the poor, the production will increase. Increased production will make investment increase. Furthermore, from the increased investment, the workforce will increase."

In carrying out consumptive zakat distribution, Baitul Mal must give zakat which can meet the basic needs of the poor. Informant 2 stated that:

"Baitul Mal must record what level of life is appropriate for the soul per day. Consumptive zakat is given to those who do not have the ability to run a business, either because of age or health factors. In the opinion of the scholars, there is a mistake, whether it is sufficiency per year or sufficiency for life."

Based on this statement, the Baitul Mal ideally records the extent of the sufficiency limit (had al-kifayah) of the poor and the poor. Thus their difficulty in fulfilling their needs can be resolved.

Apart from distributing consumptive zakat, Baitul Mal also provides zakat for the productivity of 
mustahik, especially for the poor who can work. Informant 1 stated that:

"The poor people in Aceh are not short of food, but they need more tools to work to facilitate work so that their income increases. If you are still using old tools, the resulting product is limited. If new tools are provided, it will be possible to produce even more. "

Apart from providing work equipment, the distribution of productive zakat in Aceh can also be done in the form of venture capital financing, either directly or through intermediaries (other institutions). As informant 2 explains as follows:

"Zakat can be managed by a trustworthy institution, then the proceeds will be distributed to mustahik. For example, these institutions are utilized to create a department store business, etc. Or zakat funds are placed in sharia microfinance institutions, which provide business financing for the poor without interest. Made as if credit was for the small community."
The reality of zakat distribution in Baitul Mal Aceh has been carried out in both consumptive and productive forms. Informant 3 revealed:

"BMA creates an economic
empowerment program in the
form of providing venture capital
and providing work tools for
mustahik. This is BMA's flagship
program. In addition, BMA
creates Productive village
programs. So, BMA provides
capital to the gampong to utilize
zakatfunds, in the form of groups.
To ensure the success of this
program, BMA establishes
surveillance. To avoid
irregularities, for example, the
sale of work equipment. The
working equipment of the
productive zakat program
belongs to the mustahik. "

The consumptive zakat program can help poor and needy mustahik meet their daily needs, while the distribution of productive zakat helps mustahik to work so that it can increase their income.

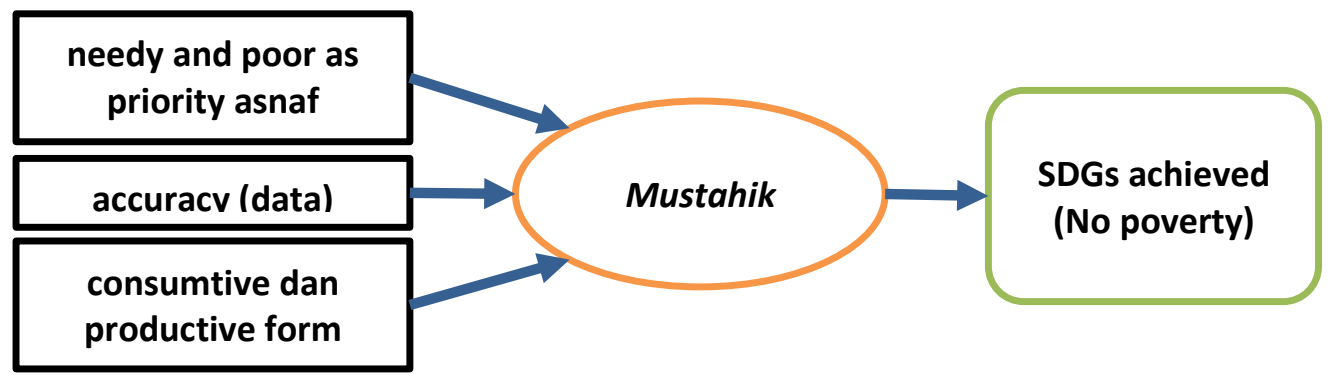

Figure 5. Optimization of Zakat Distribution to Achieve SDGs

\section{CONCLUSION}

1. In implementing the zakat mechanism to achieve the goals of sustainable development (SDGs), Baitul Mal has the role of optimizing the mechanism of transfer of assets from muzakki to mustahik, both optimizing the collection and optimizing the distribution of zakat.

2. Optimization of zakat collection is carried out with education, socialization and optimal zakat services, while optimization of distribution is carried out by prioritizing zakat for poverty 
alleviation programs, ensuring accuracy of targeting, and distribution in consumptive and productive forms.

\section{REFERENCES}

Amymie, Farhan (2017). Optimalisasi Pendistribusian dan Pendayagunaan Dana Zakat dalam Pelaksanaan Tujuan Program Pembangunan Berkelanjutan (SDGs). Anida (Aktualisasi Nuansa Ilmu Dakwah), 17(1).

Armiadi. (2008). Zakat Produktif: Solusi Alternatif Pemberdayaan Ekonomi Umat. Banda Aceh: Arraniry Press.

Ash-Shiddieqy, M.H. (2009). Pdoman Zakat. Semarang: Pustaka Rizki Putra.

Asmalia, S, Kasri, RA, Ahsan, A. (2018). Exploring the Potential of Zakah for Supporting Realization of Sustainable Development Goals (SDGs) in Indonesia. International Journal of Zakat: Special Issue on Zakat Conference.

Baitul Mal Aceh. (2019). Rencana Strategis Baitul Mal Aceh 2017-2022. Banda Aceh: Sekretariat Baitul Mal Aceh.

Baitul Mal Aceh. (2017). Directory Baitul Mal Aceh Tahun 2017. Banda Aceh: Sekretariat Baitul Mal Aceh.

Fauzia, I.Y., Riyadi, A.K. (2015). Prinsip Dasar Ekonomi Islam Perspektif Maqashid al-Syariah. Jakarta: Prenada Meda Group.

Furqani, H., Mulyany, R., Yunus, F. (2018). Zakat for Economic Empowerment of The Poor in Indonesia: Models and Implications. IQTISHADIA, 11(2).

Hafidhudddin, D. (2011). Peran Strategis Organisasi Zakat dalam Menguatkan Zakat di Dunia. Jurnal Al-Infaq, 2(1).

Harahap, LR (2018). Zakat Fund As The Starting Point of Entrepreneurship in
Order to Alleviate Poverty (SDGs Issue). Global Review of Islamic Economics and Business, 6(1).

Hoelman, M.B., dkk (2016). Sustainable Development Goals (SDGs): Panduan Untuk Pemerintah Daerah (Kota dan Kabupaten) dan Pemangku Kepentingan Daerah. Jakarta: Infid.

Huda, N, dkk. (2015). Zakat Perspektif Mikro-Makro Pendekatan Riset. Jakarta: Prenada Media Group.

Khalifah, MH, Nurzaman, MS, Nafis, MC (2017). Optimization of BAZNAS Programs on Sustainable Development Goals (SDGs): Analytic Network Process Approach (ANP). International Journal of Zakat, 2 (2).

Noor, Z. (2017). Peran Zakat dalam Mendukung Tujuan Pembangunan Berkelanjutan. BAZNAS dan UNDP.

Puskas BAZNAS (2017). Peran Zakat dalam Sustainable Development Goals untuk Pencapaian Maqashid Syariah. Jakarta: Puskas BAZNAS.

Rohim, AN (2019). Dana Sosial untuk Kesejahteraan Sosial Berkelanjutan: Tinjauan Zakat. Sosio Informa, 5(3).

Qardhawi, Y. (2005). Spektrum Zakat. Jakarta: Zikrul Hakim.

Rassanjani, S (2018). Ending Poverty: Factors That Might Influence the Achievement of Sustainable Development Goals (SDGs) in Indonesia. Journal of Public Administration and Governance, $8(3)$.

Riyaldi, M.H., Mahda, Y. (2020). Mengukur Tingkat Kepercayaan Muzakki kepada Baitul Mal Aceh. Jurnal Iqtisaduna, 6(1).

Sudira, P. (2009). Studi Mandiri Grounded Theory. Yogyakarta: UNY. 
Shaikh, SA dan Ismail, AG (2017). Role of Zakat in Sustainable Development Goals. International Journal of Zakat, 2(2)

Yusoff, W.S.W. (2008). Modern Approach of Zakat as An Economic And Social Instrument for Poverty Alleviation and Stability of Ummah. Jurnal Ekonomi dan Studi Pembangunan, 9(1)

Suriani

Faculty of Economics and Business, Syiah Kuala University, Banda Aceh, Indonesia suriani@unsyiah.ac.id

Ridwan Nurdin

Faculty of Economics and Business, Syiah Kuala University, Banda Aceh, Indonesia ridwanisa@unsyiah.ac.id

Muhammad Haris Riyaldi

Faculty of Economics and Business, Syiah Kuala University, Banda Aceh, Indonesia harisriyaldi@unsyiah.ac.id 